\author{
MAGDALENA MAKÓWKA* \\ Uniwersytet Łódzki \\ ORCID: 0000-0003-0447-832X
}

\title{
UDZIAL ANGLII W WOJNIE HABSBURGÓW Z FRANCJĄ W LATACH 1557-1558
}

W historiografii brytyjskiej udział Anglii w konflikcie Habsburgów z Francją pozostaje na marginesie rozważań nad panowaniem królowej Marii. Anglosascy badacze skupiają się w szczególności na utracie przez Albion Calais. Brakuje jednak przedstawienia szczegółów zaangażowania się Anglików w wojnę z krajem Walezjuszy. Celem niniejszego artykułu jest zarysowanie angielskiego zaangażowania w konflikt dynastii austriackiej z Francją w ostatnich latach panowania najstarszej córki Henryka VIII oraz próba przedstawienia bilansu udziału wyspy pod panowaniem Tudorów w konfrontacji na kontynencie.

Od początku panowania Marii I Tudor stosunki między Anglią a Francją pozostawały napięte. Jedną z przyczyn takiego stanu rzeczy był fakt, że ambasador francuski intensywnie wspierał konkurentkę córki Henryka VIII do korony Albionu - Jane Grey. Sama królowa zaś, gdy tylko zasiadła na tronie, oparła swą politykę zagraniczną na współpracy z rodem Habsburgów. Kontaktów z zamorskim krajem nie ułatwiało podjęcie decyzji o małżeństwie królowej z przedstawicielem dynastii austriackiej. Monarchini latem I554 r. poślubiła bowiem syna cesarza i króla Hiszpanii, księcia Filipa. Karol V bez wątpienia liczył, że związek angielskiej władczyni z jego potomkiem przyniesie dynastii austriackiej korzyści także w postaci wojskowego wsparcia. Zgodnie z zawartym przed ślubem traktatem Anglicy nie mieli jednak obowiązku zbrojnego wspierania sojuszników. Walezjusze tymczasem byli przekonani, że małżeństwo angielskiej królowej jest wymierzone przeciwko nim. Zimą I554 r. pojawiły się na francuskim dworze pogłoski o tajnym protokole, jaki miałby być zamieszczony w traktatach małżeńskich Marii i Filipa. Pogłoski głosiły, że wraz z Habsburgiem do Albionu przybędą oddziały hiszpańskie, które pomogą Anglii zdobyć Szkocję². Tego typu plotki panoszące

\footnotetext{
* Magdalena Makówka - doktorantka w katedrze historii nowożytnej Instytutu Historii Uniwersytetu Łódzkiego. Jej zainteresowania koncentrują się wokół relacji dynastii Habsburgów z Anglią, historii Anglii nowożytnej, historii dyplomacji. E-mail: magdalenamakowka@wp.pl.

1 Ambasador francuski w lipcu 1553 r. starał się przekonać księcia Northumberland, że Francja jest jedynym potencjalnym sojusznikiem Anglii pod panowaniem Jane Grey. Dodatkowo starał się wzbudzić w zwolennikach lady Grey niechęć wobec rodu Habsburgów, przekonując, iż będą oni aktywnie wspierać swoją kuzynkę - królewnę Marię; zob. M. de Noailles do Henryka II, 13 VII 1553, w: Ambassades de Messieurs de Noailles en Angleterre, t. 2, ed. Verot, Leyde 1763, s. 57-61.

2 Nicholas Wotton do Rady, 9 I 1554, w: Calendar of State Papers, Foreign Series, of the Reign of Mary, 1553-1558 (dalej: CSP, Mary I, FS), ed. W. Turnbull, London 1861, s. 47.
} 
się na dworze Walezjuszy były o tyle dziwne, iż jeden z sekretarzy cesarskiego ambasadora donosił Francuzom o tajnych szczegółach dotyczących relacji między Marią a Karolem V3.

Dalsze pogorszenie relacji pomiędzy Anglią a Francją było spowodowane faktem zaangażowania się Francuzów w bunty skierowane przeciwko królowej Marii, w szczególności powstanie Wyatta ${ }^{4}$. Uciekający na kontynent rebelianci byli ciepło przyjmowani za kanałem La Manche i mogli tam liczyć na schronienie. Ambasador angielski we Francji donosił o przyjaznym przyjęciu tego czy innego uciekiniera ${ }^{5}$.

Francuzi również mieli powody do niezadowolenia z kształtu polityki zagranicznej Albionu. Obawiano się bowiem, że wyspiarski kraj stanie się jedynie satelitą imperium Karola V. Traktat małżeński Filipa Habsburga i Marii zapowiadał ścisłą współpracę Anglii z cesarzem i wszelkimi ziemiami, jakie znajdowały się pod jego panowaniem, jednocześnie jednak podkreślał, iż Anglia nie zostanie wmieszana w konflikty Habsburgów ${ }^{6}$.

Relacje austriackiego rodu z Francją w latach 50. dalekie były od przyjacielskich. Walki między cesarzem a Walezjuszami trwały w chwili zawarcia małżeństwa między przedstawicielką rodu Tudorów a Habsburgiem. Ambasador domu austriackiego na dworze angielskim Simon Renard doradzał swemu władcy pożyczenie Anglii pieniędzy, gdyż, jeżeli Karol nie zawrze pokoju z Henrykiem II, to środki te będą mogły zostać przeznaczone właśnie na wsparcie w wojnie Habsburga ${ }^{7}$. Angielscy ambasadorzy na dworze w Brukseli stale donosili o działaniach cesarza, które mogły zwiastować wybuch walk z Francją. I tak, wiosną I554 r., John Masone informował o siłach gromadzonych przez cesarza oraz spekulował, na jakim froncie mogą one zostać użyte ${ }^{8}$. Maria tymczasem zapewniała o chęci zachowania pokoju między jej krajem a Francją. Jak twierdziła, jej małżeństwo z Filipem miało się do tego przyczyniać, gdyż zamierzała uczynić wszystko, by dynastia austriacka nie toczyła wojen ze swym długoletnim wrogiem. Zdaniem monarchini konflikt ten jest niepotrzebny i rozbija jedność chrześcijan9. Cesarz deklarował, że zgadza się z królową, iż każda wojna jest złem, lecz jednocześnie przekonywał ją o słuszności prowadzenia działań zbrojnych przeciwko Francuzom ${ }^{\mathrm{I0}}$. Ambasador Anglii w Brukseli, John Masone, na początku I555 r. był tymczasem przekonany, że zwłoka w negocjacjach między cesarzem a Francją wynika właśnie z nadziei Habsburga na uzyskanie pomocy ze strony Marii ${ }^{\text {II }}$.

\footnotetext{
Nicholas Wotton do Marii I, 28 IV 1554, w: CSP, FS, Mary I, s. 78.

4 Powstanie Wyatta wybuchło jako sprzeciw części angielskiego społeczeństwa wobec planowanego małżeństwa królowej z Filipem Habsburgiem. Szczegółowe informacje dotyczące przebiegu powstania zob. E. Simons, The Queen and the rebel. Mary Tudor and Thomas the Younger, London 1964; W. Wiatt, The Lost History of Wyatt's Rebellion, „Renaissance News”, 1962, vol. 15, No. 2, s. 129-133. Temat roli Francji w powstaniu został omówiony w: E. Harbison, French Intrigue at the Court of Queen Mary, „The American Historical Review”, 1940, vol. 45, No. 3, s. 533-551.

5 Np. Nicholas Wotton do Marii I, 29 IV 1554, w: CSP, FS, Mary I, s. 79.

6 Act for the Marriage of Queen Mary to Philip of Spain, w: Select Documents of English Constitutional History, ed. G. Adams, H. Stephens, London 1920, s. 281-184.

7 Simon Renard do Karola V, 27 IV 1554, w: Calendar of State Papers, Spain (dalej: CSP, Spain), vol. 13, ed. R. Tyler, London 1954, s. 230.

8 John Masone do Marii I, 12 V 1554, w: CSP, FS, Mary I, s. 81.

9 Maria I do Nicholasa Wottona, 29 V 1554, w: CSP, FS, Mary I, s. 88-89.

10 John Masone do Marii I, 11 IV 1555, w: CSP, FS, Mary I, s. 162.

11 John Masone do Williama Petre, 10 I 1555, w: CSP, FS, Mary I, s. 149.
} 
Relacjami francusko-angielskimi szybko zainteresował się król Filip, który rozmawiał z członkami Tajnej Rady na temat tego, czy są oni gotowi na zerwanie przyjaznych relacji z tym krajem, czy też nie ${ }^{\text {12 }}$. W rozgrywki między Francją a cesarzem w I555 r. Anglię wciągnęli jednak Francuzi, którzy zaproponowali, aby Maria została mediatorem pomiędzy zwaśnionymi stronami. Królowa z ochotą przystała na tę propozycję, zapewne spodziewając się, że będzie mogła pomóc teściowi w prowadzeniu jego wielkiej polityki. Anglicy jako swych komisarzy wysłali kanclerza hrabiego Arundel i Williama Pageta. Szybko mieli się przekonać, że prowadzenie negocjacji nie będzie należało do najłatwiejszych zadań ${ }^{13}$. Musieli bowiem negocjować z najbardziej wytrawnymi politykami ówczesnej Europy, gdyż jednym z negocjatorów ze strony Karola V był biskup Arras - Antoine Perrenot de Granvelle. Kwestii spornych było zaś bez liku. Zanim komisarze zasiedli do stołu, aby obradować nad zakończeniem wojny, musieli ustalić szereg innych spraw, między innymi kwestie proceduralne czy też pozycje, jakimi na czas rozmów powinna zajmować francuska $\operatorname{armia}^{14}$. Negocjacje ciągnęły się przez wiele tygodni. Ostatecznie Francja i Habsburgowie I5 lutego 1556 r. zawarli pięcioletni rozejm. O tym, że porozumienie to okazało się warte nie więcej niż papier, na którym je spisano, zadecydowało zachowanie przywódcy pochodzącego z Półwyspu Apenińskiego, a mianowicie papieża.

O roli głowy Kościoła katolickiego w napędzaniu działań wojennych wymierzonych w Habsburgów donosił także angielski wysłannik ${ }^{15}$. Na tronie w Stolicy Piotrowej zasiadał wówczas Giovanni Carafa, który przyjął imię Pawła IV. Był to zawzięty przeciwnik protestantów, potępiający jakiekolwiek negocjacje z nimi. Do tego miał antyhiszpańskie poglądy, wynikające z tego, iż uznawał mieszkańców Półwyspu Iberyjskiego za okupantów Italii. Dlatego też nie wahał się wspierać Francuzów w walce przeciwko Habsburgom ${ }^{16}$. Gdy dotarły do niego pogłoski o tym, że Filip może chcieć wystąpić przeciwko Henrykowi II, przestrzegł młodego władcę słowami: „uwierz nam, drogi synu, nie będzie żadnej wiktorii, nikt nie pragnie zwycięstwa za taką cenę" "' nie było niczym nowym. Jako władca Państwa Kościelnego, papież musiał dbać o swoje interesy w Italii, te zaś często nie były zbieżne z celami polityki rodu Habsburgów. Dlatego też dyplomacja czy to Karola V, czy też Filipa musiała liczyć się z możliwością stanięcia w szranki z duchowym przywódcą katolików ${ }^{18}$. Ojciec święty namawiał Marię I, aby wpłynęła na męża i pohamowała jego wojenne zapędy ${ }^{19}$. Tymczasem sam 27 lipca 1557 r. wystąpił z publicznymi oskarżeniami wymierzonymi w cesarza. Następnie zaś poprosił o zbrojne wsparcie Francuzów, którzy chętnie go udzielilii ${ }^{20}$.

Wybuch kolejnego konfliktu habsbursko-francuskiego tym razem miał dosięgnąć również Anglii. W kraju Henryka II obawiano się wsparcia, jakiego mógł oczekiwać Filip II, po abdykacji swego ojca król Hiszpanii i władca Niderlandów. Wsparcie kraju żony Habsburga

12 Simon Renard do Karola V, 14 XI 1554, w: CSP, Spain vol. 13, s. $82-83$.

13 Delegacja pokojowa do Karola V, 20 V 1555, w: CSP, Spain, s. 175.

14 Delegacja pokojowa do Karola V, 23 V 1555, w: CSP, Spain, s. 176-179.

15 Edward Carne do Filipa II i Marii I, 10 IV 1557, w: CSP, FS, Mary I, s. 292.

16 R. Fischer-Wollpert, Leksykon papieży, tłum. M. Krzyszkowski, Kraków 1996, s. 134-135.

17 Cyt. za: J. Edwards, Mary I: England's Catholic Queen, Yale 2011, s. 285.

18 M. Levin, Agents of Empire: Spanish Ambassadors in Sixteenth-century Italy, Ithaca 2005, s. 68-69.

19 Ibidem.

20 P. Tafiłowski, Wojny wloskie 1494-1559, Zabrze 2007, s. 388-390. 
oznaczałoby zaś, że Francja została otoczona przez państwa znajdujące się pod władaniem rodu austriackiego. Dlatego też nad Loarą powstał plan uderzenia wyprzedzającego wymierzonego w Anglików. Francuzi nie zapomnieli o swoich pomysłach wywołania powstania w kraju pod panowaniem Marii I i w tym celu planowali wysłać na wyspę zbiegłych wcześniej Anglików, którzy mieli zapoczątkować wystąpienie przeciwko królowejej ${ }^{21}$ W kwietniu I557 r. zaopatrzyli w okręty Thomasa Stafforda, który przybił do Anglii i zajął zamek w Scarborough. Posiadając pod swoją kontrolą tak rozległe obszary, ogłosił detronizację królowej, która zadanie pokonania go powierzyła hrabiemu Westmoreland. Ten zaś bez większych trudności pobił przybysza. Incydent ten przekonał Anglików o tym, iż Francuzi nie są problemem jedynie dla Niderlandów czy innych posiadłości domu austriackiego w Europie, ale także dla nich samych ${ }^{22}$.

Aby zachęcić Anglików do udziału w wojnie, Filip powrócił do kraju w marcu $1557 \mathrm{r}^{23}$. Nie miał łatwego zadania, gdyż do zaangażowania się w konflikt musiał przekonać nie tylko zakochaną w nim żonę, ale przede wszystkim członków Tajnej Rady. Ci zaś do wzięcia udziału w walkach nastawieni byli sceptycznie. Argumentowali, że jest to sprzeczne z zawartym traktatem małżeńskim. Dodatkowo wyjątkowo intensywnie przeciw zaangażowaniu się w wojnę wypowiadał się kardynał Reginald Pole, któremu nie podobały się działania Habsburgów w Italii wymierzone w papieża Pawła IV ${ }^{24}$.

Już 7 czerwca 557 r. Anglia wypowiedziała jednak Francji wojnęę. Był to niewątpliwy sukces Filipa II, potrzebującego angielskiej floty, którą teraz mógł dysponować ${ }^{6}$. Ponadto do Calais udał się oddział pod wodzą hrabiego Pembroke, miał on wspierać Hiszpanów i Niderlandczyków na lądzie ${ }^{27}$. Wyekspediowanie poddanych Marii I za kanał La Manche nie należało do najłatwiejszych zadań. Zdaniem wysłannika syna Karola V problemy czynili sami Anglicy jako naród kłótliwy i trudny w obyciu ${ }^{28}$. Nie bez przeszkód toczyły się rozmowy także po przybiciu na kontynent. Małżonek angielskiej królowej żalił się, iż w trakcie rozmów o kształcie angielskiego wsparcia oczekiwania wyspiarzy były mniejsze niż po przekroczeniu kanału. Jako przykład podawał liczbę wozów, jakich miało dostarczyć habsburskie dowództwo. Wstępnie rozmawiano o dwunastu, później dowódcy z Albionu oczekiwali osiemdziesięciu. Król liczył, że w sprawach aprowizacyjnych uda mu się jednak dojść do porozumienia z hrabią Pembroke ${ }^{29}$. Filipowi II zależało na wsparciu, jakiego mogli dostarczyć Anglicy. Zachęcał angielskiego dowódcę, aby bez zwłoki dołączył do jego oddziałów ${ }^{30}$. Hrabia Pembroke przywiódł ze sobą korpus złożony z I8 tysięcy ludzi. Początkowo

\footnotetext{
21 Simon Renard do Filipa Habsburga, 13 VI 1556, w: CSP, Spain, s. 270.

22 C. Davies, England and the French War, 1557-1559, w: The Mid-Tudor Polity c. 1540-1560, ed. J. Loach,

R. Tittler, London 1985, s. 161.

23 Filip Habsburg opuścił Anglię w 1555 r., aby objąć władzę nad Niderlandami oraz terytoriami hiszpańskimi i włoskimi, które miał odziedziczyć po zrzeczeniu się władzy przez cesarza Karola V. H. Kelsey, Philip of Spain. King of England: the Forgotten Sovereign, London 2012, s. 150.

24 L. Porter, Maria Tudor, tłum. A. Tuz, Kraków 2013, s. 439.

25 Deklaracja poczyniona w Londynie 7 VI deklarująca wojnę z Francją, 7 VI 1557, w: CSP, Spain, s. 293.

26 Filip Habsburg do Pero Menéndezy, 30 VI 1557, w: CSP, Spain, s. 299.

27 Hrabia Pembroke do Filipa Habsburga, 19 VII 1557, w: CSP, Spain, s. 304.

28 Pero Menéndez do Filipa Habsburga, 8 VII 1557, w: CSP, Spain, s. 302.

29 Filip Habsburg do Juan de Ayali, 22 VII 1557, w: CSP, Spain, s. 305.

30 Filip Habsburg do hrabiego Pembroke, 4 VIII 1557, w: CSP, Spain, s. 308.
} 
Filip rozważał wykorzystanie tych oddziałów do okupowania kilku miejscowości na tyłach armii, ostatecznie uznał jednak, że dołączą one do głównej armii Habsburgów ${ }^{31}$. Siły te, aczkolwiek spóźnione, udały się pod Saint Quentin oblegane przez wojska hiszpańskie ${ }^{32}$.

Anglia tymczasem musiała się zmierzyć z kolejnym problemem, gdyż wojnę wypowiedziała jej wierna sojuszniczka Francji - Szkocja. Anglicy chcieli w związku z tym dokonać prewencyjnego ataku na sąsiada. Odradzał im to Filip, który nie chciał zmniejszać potencjalnych sił, które mogły wesprzeć jego oddziały w walkach na kontynencie ${ }^{33}$. Szkoci tymczasem atakowali irlandzkie posiadłości Anglików ${ }^{34}$. Dodatkowo poddani Marii I musieli zmierzyć się z konsekwencjami finansowymi wojny toczonej przez Habsburga. Długi, jakich w Niderlandach narobił król, sprawiły, że także angielski rząd odczuł na własnej skórze niechęć Niderlandczyków do dalszego wyzbywania się gotówki, co powodowało uszczuplenie środków pieniężnych, jakimi mogli oni płacić za towary przybywające z Angliij5.

Wojna tymczasem toczyła się szczęśliwie dla Filipa. Największym sukcesem w kampanii z I557 r. była wygrana bitwy pod Saint-Quentin, która nastąpiła Io sierpnia. Wojska Filipa pod dowództwem księcia Sabaudii Emanuela Filiberta pokonały siły francuskie. Trzy tysiące Francuzów poległo, zaś siedem tysięcy dostało się do niewoli. Sukces ten bez wątpienia podbudował morale w armii Habsburga, lecz nie oznaczał końca konfliktu. Zwłaszcza, że Francuzi postanowili za wszelką cenę odzyskać tereny zajęte przez wroga. Także Calais znalazło się w niebezpieczeństwie. Henryk II Walezjusz chciał odzyskać ostatni angielski skrawek na swej ziemi od początku rządów. Jednak z różnych przyczyn wewnętrznych i zewnętrznych działania mające wprowadzić jego chęci w życie odwlekały się. Kiedy na tron wstąpiła Maria, Francuzi zdawali sobie sprawę, że potrzeba odzyskania Calais wzrosła ze względu na prohabsburskie nastawienie królowej Anglii. Ponadto w angielskim mieście schronienia szukało wielu protestantów zarówno pochodzenia francuskiego jak i angielskiego. Do tego było to niezwykle ważne dla Anglików miejsce handlu wełną. W dokumentach Tajnej Rady niejednokrotnie pojawiają się informacje o wysyłaniu tam owczego runa ${ }^{36}$. Sama twierdza była niezbyt dobrze przygotowana do oblężenia. Już w maju I557 r. gubernator Calais, Thomas Wentworth, donosił, że bez naprawy murów oraz uzupełnienia zapasów amunicji szybko zostanie zdobyta przez wroga ${ }^{37}$. Utrzymanie Calais od dziesięcioleci było dla angielskiego skarbu dużym obciążeniem. Aby zapobiec odbiciu miasta przez Francuzów należało zadbać o odpowiedni stan fortyfikacji oraz zapasy prochu i broni. W czasach Edwarda VI angielski przyczółek na kontynencie odczuwał kłopoty finansowe, z jakimi borykano się w Anglii. W trakcie panowania Marii I ambasador na dworze Henryka II Nicholas Wotton ostrzegał o możliwości francuskiego ataku na Calais, do tego przy udziale Anglików szukających

\footnotetext{
Ibidem.

L. Porter, op. cit., s. 440.

33 Filip Habsburg do Luisa de Carvajala, 8 VIII 1557, w: CSP, Spain, s. 310.

34 A. Blakeway, The Anglo-Scottish War of 1558 and the Scottish Reformation, ,The Journal of Historical Association", 2017, vol. 102, No. 350, s. 207.

35 Sir Thomas Gresham on the fall of exchange, 1558,w: English economic history. Select documents, eds A. Bland, P. Brown, R. Tawney, London 1914, s. 416.

36 Była to jedna z kwestii poruszanych w trakcie obrad Rady w listopadzie 1551. Acts of the Privy Council of England, vol. 3, ed. J. Dasent, London 1891, s. 406.

37 Thomas Wentworth i rada Calais do Marii I, 23 V 1557, w: CSP, FS, Mary I, s. 310-311.
} 
schronienia na francuskim dworze, nie pociągnęło to jednak zwiększenia nakładów finansowych na twierdzę ${ }^{38}$.

Pod koniec I557 r. to właśnie w stronę angielskiej osady na francuskiej ziemi skierowała się armia Henryka II Walezjusza. Działania te były nieco zaskakujące, gdyż bardziej prawdopodobne wydawało się, że Francuzi będą chcieli odzyskać świeżo zdobyte przez Filipa Habsburga miejscowości, takie jak Saint-Quentin czy Ham. Mimo prób zachowania celu operacji w tajemnicy jeden z habsburskich dowódców słyszał plotki, że siły Henryka II grupują się w okolicach Sommy właśnie w celu zaatakowania Calais ${ }^{39}$. Również gubernator

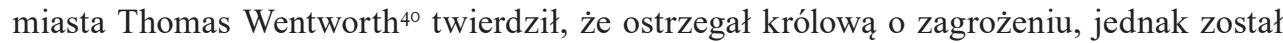
zignorowany. W rzeczywistości był jednak przekonany, że celem Francuzów nie jest Calais i taką informację przekazywał oficerom Filipa ${ }^{4}$. Na jego usprawiedliwienie można jednak dodać, że Francuzi wyjątkowo sprawnie przeprowadzili mobilizację swych wojsk. Już na początku grudnia zgromadzili w okolicach Abbeville oddziały liczące I6 tysięcy, w skład których wchodziła piechota i kawaleria. Część tych sił zdążyła przybyć w ostatniej chwili, gdyż jeszcze w listopadzie została wysłana do Flandrii ${ }^{42}$. Wentworth 27 grudnia zaaranżował spotkanie z dowódcą Gusisnes lordem Greyem w celu omówienia problemu. Jednocześnie informował królową, że chociaż istnieje prawdopodobieństwo ataku na miasto, to nie ma potrzeby podejmowania pilnych działań ${ }^{43}$.

Główne oddziały Francuzów pod dowództwem księcia de Guise stanęły u bram Calais 3I grudnia I557 r. Anglicy starali się bronić, lecz zdawali sobie sprawę z tego, że nie mają zbyt dużych szans, zwłaszcza w obliczu zaciętości Francuzów i tego, że mogą liczyć oni na przybycie kolejnych posiłków ${ }^{44}$. Thomas Wentworth jeszcze w sylwestra zwrócił się o pomoc do Filipa Habsburga ${ }^{45}$. Ten zaś w odpowiedzi zachęcał do obrony twierdzy oraz poinformowania o poważnym niebezpieczeństwie także królowej Marii ${ }^{46}$. Na zwrócenie się o wsparcie do Anglii było jednak za późno. Niekorzystny wiatr utrudniał bowiem żeglugę po kanale La Manche. Ostatnią nadzieją dla angielskiej przystani na francuskiej ziemi były znajdujące się niedaleko oddziały króla Anglii i Hiszpanii. O ich wsparcie swego władcę prosił więc gubernator Calais ${ }^{47}$. Filip II zwrócił się do księcia Sabaudzkiego, aby ruszył w stronę Calais, jednocześnie nakazał admirałowi swej floty opuszczenie miasta i dołączenie do angielskiej flotylli. Habsburg nie widział bowiem dużych szans na obronę twierdzy, a jedynym, na czym mu zależało, było zapobiegnięcie wpadnięciu hiszpańskich zasobów we francuskie ręce $^{4}$. Filip już 2 stycznia napisał jednak list do angielskiej Tajnej Rady, w której wzywał

\footnotetext{
38 S. Rose, Calais. An English Town in France, 1347-1558, Woodbridge 2008, s. 157-159.

39 D. Potter, The duc de Guise and the Fall of Calais, 1557-1558, „The English Historical Review”, 1983, vol. 98, No. 388, s. 483-488.

40 Thomas Wentworth stanowisko piastował od IX 1553 r. W 1557 r. miał niewiele ponad trzydzieści lat. W Calais przebywała razem z nim ciężarna żona oraz dwuletni syn. S. Rose, op. cit., s. 161.

41 Thomas Wentworth do Marii I, 26 XII 1557, w: CSP, FS, Mary I, s. 351.

42 D. Potter, op. cit., s. 491.

43 S. Rose, op. cit., s. 162

44 Thomasa Wentworth do Marii I, 1 I 1558, w: CSP, FS, Mary I, s. 354.

45 Lord Wentworh do Filipa Habsburga, 31 XII 1557, w: CSP, Spain, s. 320.

46 Filip II do lorda Wentwortha, 2 I 1558, w: CSP, Spain, s. 321.

47 Lord Wentworth do Filipa Habsburga, 2 I 1558, w: CSP, Spain, s. 321-322.

48 Filip Habsburg do Luisa de Carvajala, 7 I 1558, w: CSP, Spain, s. 323.
} 
Anglików do zmobilizowania się i obronienia Calais przed dostaniem się w ręce wroga. Przekonywał, że atak ten jest zagrożeniem nie tylko dla mieszkańców Anglii, ale także dla planów samego Habsburga ${ }^{49}$. Słowa zachęty na niewiele się zdały i 7 stycznia 558 r. Anglia utraciła swój ostatni przyczółek na francuskiej ziemi. O porażce poinformował króla w liście z Io stycznia Edward Dudley, który miał pretensje do Rady Calais o niedostateczną obronę i postępowanie wbrew radom doświadczonych wojskowych, którzy wysyłali je obrońcom miasta korespondencyjnie ${ }^{50}$.

Filip zwrócił się do Tajnej Rady, aby wyrazić swój smutek z powodu upadku twierdzy. Jak pisał:

„Czujemy wielki ból i niepokój z powodu upadku Calais, większy niż możemy wyrazić słowami, ze względu na znaczenie tego miejsca, z którego zdajemy sobie sprawę, i naszej troski o interesy Królestwa Anglii, które mamy w sercu tak jak i inne nasze sprawy. Byłoby to jednak dla nas jeszcze gorsze, gdybyśmy wierzyli, że zaniedbaliśmy nasze obowiązki w jakikolwiek sposób. Ale w chwili, gdy usłyszeliśmy o francuskich postępach, z największą troską zadbaliśmy o ulżenie Calais, zarówno drogą morską, jak i lądową, co Juan de Ayala, zgodnie z naszymi instrukcjami, wyjaśnił Wam kilka dni temu. Wierzymy, że dowiedzieliście się od niego o pomocy i planach zniesienia oblężenia, które mieliśmy, mieliśmy podstawy mieć nadzieję, że [działania te MM] zakończyłyby się sukcesem, gdyby ci, którzy dowodzili fortecą, uczynili minimum niezbędne do ich wykonania. Teraz, jednakże sytuacja całkowicie się zmieniła i zostanie podjęty nowy kurs działania"51.

Kiedy Filip zrzucił już z siebie brzemię odpowiedzialności za porażkę, przeszedł do snucia planów dalszej kampanii przeciwko Francji. Proponował więc, aby oddziały, które już nie muszą bronić Calais, wykorzystać na innych polach walki ${ }^{52}$. Liczył także na uzyskanie pożyczki od Anglii, na przeszkodzie temu stało jednak to, że zgodę na to musiał wyrazić parlament ${ }^{53}$. Jak przekonywał Habsburg, środki te miały zostać przeznaczone na zapewnienie bezpieczeństwa Albionowi ${ }^{54}$. Jednocześnie hiszpański król stwierdzał, że nie może pozwolić na eksport ze swoich krajów prochu. Na marginesie listu do hrabiego Ferii szczerze stwierdzał, że sam go potrzebuje ${ }^{55}$. Aby zachęcić Anglików do dalszego wysiłku wojennego, Filip

49 J. Edwards, op. cit., s. 310.

50 Edward Dudley do Filipa II, 10 I 1558, w: La Guerre de 1557 en Picardie. Bataille de Saint-Laurent, siège de Saint-Quentin, prises du Catelet, de Ham, de Chauny [...], ed. E. Lemaire, H. Courteault i inni, Saint-Quentin 1896, s. 404-405.

51 Tłumaczenie własne autorki: ,We have felt great pain and anxiety on account of the fall of Calais greater indeed than we can express in words, because of the importance of that place, which you realise, and our concern for the interests of the Kingdom of England, which we have as much at heart as our other affairs. It would, however, have been still bitterer to us if we had felt that we had failed in any way of our duty. But the moment we heard of the French advance we took the greatest care to provide relief for Calais, both by sea and by land, as we instructed Juan de Ayala to explain to you some days ago. We believe you have heard from him of the assistance and plans for raising the siege which we had good reason to hope would have been successful, if those in command of the fortress had done the minimum necessary for their execution. Now, however, the position is entirely changed, and a new course of action has to be devised”. Filip Habsburg do Tajnej Rady, 21 I 1558, w: CSP, Spain, s. 340.

52 Ibidem.

53 Hrabia Feria do Filipa Habsburga, 2 II 1558, w: CSP, Spain, s. 349-350.

54 Filip Habsburg do hrabiego Feria, 15 II 1558, w: CSP, Spain, s. 360.

55 Filip Habsburg do Juana de Figueroa, 18 II 1558, w: CSP, Spain, s. 363-364. 
przekonywał, że są bardzo duże szanse na odzyskanie Calais ${ }^{56}$. Skutki zdobycia Calais odczuli także przebywający w Anglii Francuzi, którym w styczniu I558 r. nakazano w ciągu 40 dni opuścić królestwo pod panowaniem Marii ${ }^{57}$. Sami Anglicy także zaczęli doszukiwać się zdrady we własnych szeregach. Thomas Wentworth posądzał o zdradę własnych podwładnych, jego zdaniem to przez ich działania Calais wpadło w ręce wroga. Tymczasem Hiszpanie sądzili, że zdradził sam Wentworth, który znany był ze swych protestanckich poglądów ${ }^{58}$. Dowodzący obroną twierdzy nie miał zbyt dużych możliwości obrony, gdyż pozostawał we francuskiej niewolis9. Utrata Calais wiązała się dla Tajnej Rady z wieloma problemami logistycznymi, jak chociażby przetransportowaniem ze zdobytego miasta obecnych tam kobiet i dziecíi ${ }^{60}$.

Tymczasem królowi udało się doprowadzić do tego, że lordem admirałem został mianowany lord Clinton, któremu Filip ufał. Nominacja była rezultatem działan Habsburga, sugerującego ją żonie ${ }^{61}$. Wpływ Habsburga na sprawy związane z toczącą się wojną był tak wielki, że Maria nie chciała bez jego wiedzy zgodzić się na wymianę jeńców. Lady Grey, błagająca o wymianę męża, musiała więc nerwowo oczekiwać na dostarczenie wiadomości od króla, czy wyraża zgodę na przeprowadzenie akcji, czy też nie ${ }^{62}$. Ten zaś stwierdził, że pan La Rochefoucauld, na którego miano wymienić lorda Grey’a znajduje się w rękach hrabiego Mansfeld i Filip nie ma wpływu na jego losy ${ }^{63}$. Sam król nie miał nic przeciwko tej wymianie i działania w tej kwestii zostawiał w rękach żony ${ }^{64}$. W I558 r. Habsburgowie zwrócili się ponadto do angielskich kupców rezydujących w Niderlandach z prośbą o pożyczkę, która miała wesprzeć wysiłek wojenny domu austriackiego, podejmowany wszak także w interesie Anglii. Negocjacje w tej sprawie prowadził Wilhelm Orański ${ }^{65}$.

Wiosna 1558 r. przyniosła ze sobą początek negocjacji pokojowych. Na miejsce rozmów wybrano miejscowość Cateau Cambresis. W czasie negocjacji pokojowych prowadzonych z Francją przedstawiciele Filipa dbali również o angielskie interesy, między innymi przedstawiając przeciwnikom długi historyczny wywód, z którego wynikało, iż Calais powinno należeć do Angliii ${ }^{66}$. Dodatkowo władca Hiszpanii informował Anglików, że istnieje nadzieja na przeprowadzenie we wrześniu kampanii, która skończy się właśnie odzyskaniem angielskiego przyczółku na kontynencie. Filip w trakcie rozmów z Francuzami reprezentował interesy kraju, którego był królem poprzez małżeństwo. Odzyskanie Calais bez wątpienia przyniosłoby korzyści strategiczne także jemu, lecz przede wszystkich usatysfakcjonowałoby to rodaków jego żony. W Anglii nie łudzono się co do szans na odzyskanie miasta,

\footnotetext{
56 Filip Habsburg do Juana de Figueroa, 15 II 1558, w: CSP, Spain, s. 360.

${ }^{57}$ By the Kynge and the Quene where at the openyng and begynnyng of the warres with the Frenche, the Queenes Maiestie caused her proclamation to be made and therein gave warning ... to so many of that nation inhabitynge within this realme ... to depart the same, within forty daies ..., London 1558.

58 C. Davies, op. cit., s. 175.

59 A. F. Pollard, Wentworth, Thomas (1525-1584), w: Dictionary of National Biography, vol. 60, London 1900, s. 267.

60 Acts of the Privy Council of England, vol. 6, ed. J. Dasent, London 1893, s. 246.

61 Filip Habsburg do Juan de Figueroa, 15 II 1558, w: CSP, Spain, s. 361.

62 Hrabia Feria do Juan de Figueroa, 22 II 1558, w: CSP, Spain, s. 363.

63 Filip Habsburg do Juan de Figueroa, 26 II 1558, w: CSP, Spain, s. 364.

64 Filip Habsburg do Juan de Figueroa, 27 II 1558, w: CSP, Spain, s. 365.

65 Wilhelm Orański do Filipa Habsburga, 11 I 1558, w: CSP, Spain, s. 329.

${ }_{66}$ Zob. np.: komisja pokojowa do Filipa Habsburga, 26 i 27 X 1558, w: CSP, Spain, s. 420-425.
} 
nadzieję straciła nawet królowa ${ }^{67}$. Filip obiecywał jednak, że nie zawrze pokoju z Francją bez odzyskania angielskiego przyczółku. Szybko jednak nawet on zdał sobie sprawę z tego, iż potrzebuje pokoju, zaś pogarszający się stan zdrowia Marii sprawiał, że odzyskanie angielskich ziem stawało się dla króla coraz mnie istotne ${ }^{68}$. Śmierć królowej w listopadzie 1558 r. i wstąpienie na tron jej siostry Elżbiety spowodowało, iż interesy Albionu i Habsburgów przestały być zbieżne. Ostatecznie pokój kończący rywalizację Francji i Hiszpanii został podpisany w kwietniu I559 r. w Cateau-Cambresis. W traktacie tym zaznaczono, że Calais wróci do Anglii, jeżeli Francja otrzyma 500 tysięcy écus w przeciągu ośmiu lat. Dodatkowo w tym czasie kraj Elżbiety I miał nie uczestniczyć w działaniach przeciwko państwu zza kanału La Manche. Albion jednak już w I560 r. wmieszał się we francuskie wojny religijne i tym samym Calais nigdy nie wróciło do wyspiarzy ${ }^{69}$.

Udział Anglii w wojnie z Francją przyniósł wyspiarskiemu krajowi katastrofalne skutki. Stracony został ostatni przyczółek na kontynencie, jakim było Calais. Do tego kilkumiesięczna wojna zaprzepaściła starania o osiągnięcie stabilizacji finansowej skarbu, do czego dążono przez poprzednie lata ${ }^{70}$. Bez wątpienia okazało się to największą stratą w ramach realizowania polityki opartej na ścisłych związkach z dynastią Habsburgów. Mimo to nie można jednoznacznie potępić udziału Anglii w wojnie z Francją u boku Filipa. Gdyby losy wojny potoczyły się nieco inaczej, Albion mógł odnieść niebagatelne korzyści ze stania u boku zwycięscy. Nie można też zapominać o tym, że relacje z Francją od samego panowania Marii były złe. Francuzi wspierali wszystkie wymierzone w królową spiski, ambasador Henryka II Walezjusza aktywnie angażował się w pomoc rebeliantom. Wydaje się więc, że przyłączenie się do wojny przeciwko wrogowi było czymś zupełnie naturalnym. Ponadto strata Calais była wynikiem także wielu lat zaniedbań fortyfikacji i zaopatrzenia twierdzy.

Trzeba też przyznać, że angielskie oddziały stanowiły wsparcie dla Filipa Habsburga, który dzięki nim tanim kosztem zwiększył liczebność swoich jednostek. Można uznać to za największą zaletę jego kilkuletniego małżeństwa z Marią. Jednocześnie nie należy stwierdzać, iż Filip traktował Anglików jedynie instrumentalnie. Ich udział jako poddanych jego żony, podległych przez małżeństwo także jemu, musiał być dla niego oczywisty. Ponadto Habsburg starał się dbać także o angielskie interesy, czego dowodzą chociażby negocjacje pokojowe, w trakcie których poruszano sprawę zwrotu Calais. Okazało się jednak, że działania te były spóźnione i nie przyniosły spodziewanych rezultatów. Rychłe wstąpienie na tron Elżbiety I utrwaliło jedynie wizerunek przebiegłego hiszpańskiego księcia wykorzystującego Anglików, którzy to wplątani w nie swoją wojnę utracili Calais.

\section{The participation of England in the Habsburg war with France in the years 1557-155 Abstract}

The purpose of this article is to present English participation in the war between France and the Habsburg Monarchy during the reign of Mary I. The queen's husband was Philip Habsburg, son of Emperor, and he persuaded the English Secret Council to participate in

\footnotetext{
67 J. Edwards, op. cit., s. 316-317.

68 D. Loades, Mary Tudor, London 1996, s. 306.

69 S. Rose, op. cit., s. 169-170.

70 D. Loades, The Reign of Mary Tudor: Historiography and Research, „Albion: A Quarterly Journal Concerned with British Studies", 1989, vol. 21, No. 4, s. 554.
} 
the conflict. This war proved to have catastrophic consequences for England, due to the loss of Calais by the country of Mary I.

Keywords: Mary I, Philip Habsburg, war, Calais

\section{BIBLIOGRAFIA}

\section{Źródla:}

Acts of the Privy Council of England, vol. 3, 6, ed. J. Dasent, London I89I, I893.

Ambassades de Messieurs de Noailles en Angleterre, t. 2, ed. Verot, Leyde 1763.

By the Kynge and the Quene where at the openyng and begynnyng of the warres with the Frenche, the Queenes Maiestie caused her proclamation to be made and therein gave warning ... to so many of that inhabitynge within this realme ... to depart the same, within forty daies ..., London 1558 .

Calendar of State Papers, Foreign Series, of the Reign of Mary, I553-I558, ed. W. Turnbull, London I86I.

Calendar of State Papers, Spain, vol. I3, ed. R. Tyler, London I954.

English economic history. Select documents, eds A. Bland, P. Brown, R. Tawney, London I9I4. La Guerre de 1557 en Picardie. Bataille de Saint-Laurent, siège de Saint-Quentin, prises du Catelet, de Ham, de Chauny [...], ed. E. Lemaire, H. Courteault i inni, Saint-Quentin I896. Select Documents of English Constitutional History, ed. G. Adams, H. Stephens, London I920.

\section{Opracowania:}

Blakeway A., The Anglo-Scottish War of 1558 and the Scottish Reformation, „The Journal of Historical Association", 20I7, vol. I02, No. 350, s. 20I-224.

Davies C., England and the french war, I557-I559, w: The Mid-Tudor Polity c. 1540-I560, ed. J. Loach, R. Tittler, London 1985, s. I59-I84.

Edwards J., Mary I: England's Catholic Queen, Yale $20 \mathrm{II}$.

Fischer-Wollpert R., Leksykon papieży, tłum. M. Krzyszkowski, Kraków 1996.

Harbison E., French Intrigue at the Court of Queen Mary, „The American Historical Review”, I940, vol. 45, No. 3, s. 533-55I.

Kelsey H., Philip of Spain. King of England: the forgotten sovereign, London 2012.

Levin M., Agents of Empire: Spanish Ambassadors in Sixteenth-century Italy, Ithaca 2005. Loades D., Mary Tudor, London I996.

Loades D., The Reign of Mary Tudor: Historiography and Research, „Albion: A Quarterly Journal Concerned with British Studies", I989, vol. 2I, No. 4, s. 547-588.

Pollard A. F., Wentworth, Thomas (I525-I584), w: Dictionary of National Biography, vol. 60, London I900, s. 265-267.

Porter L., Maria Tudor, tłum. A. Tuz, Kraków 2013.

Potter D., The duc de Guise and the Fall of Calais, I557-I558, „The English Historical Review", I983, vol. 98, No. 388, s. 48I-5I2.

Rose S., Calais. An English Town in France, I347-I558, Woodbridge 2008.

Simons E., The Queen and the rebel. Mary Tudor and Thomas the Younger, London 1964.

Tafiłowski P., Wojny włoskie I494-I559, Zabrze 2007.

Wiatt W., The Lost History of Wyatt's Rebellion, „Renaissance News”, I962, vol. I5, No. 2, S. I29-I33. 